\title{
Tree-Rings, Timbers and Trees: a dendrochronological survey of the 14th-century cog, Doel 1
}

\author{
Kristof Haneca \\ Flanders Heritage Agency, Koning Albert II-laan 19, bus 5, 1210 Brussels, Belgium, \\ Kristof.Haneca@rwo.vlaanderen.be
}

\author{
Aoife Daly \\ Dendro.dk, Fuglsang Alle 111,DK-2700Brønshøj,Denmark, dendro@dendro.dk
}

In 2000, the remains of a $\operatorname{cog}$, Doel 1, were found in Doel, Belgium. Wood species identification of all ship timbers and smaller elements was performed. European oak was the dominant species, followed by alder that was used for the fairings. In total 150 ring-width series were recorded. The construction date was set at AD 1325/26 and the timbers proved to originate from forests along the rivers Elbe and Weser. For the bottom strakes a strict symmetrical layout was observed. The keel plank was hewn from a trunk with a slightly earlier felling date. Repairs were performed with high-quality boards, some with a southern Baltic provenance.

(C) 2013 The Authors

Key words: dendrochronology, provenance, timber conversion, cog, 14th century, archaeology.

I n September 2000, a mechanical excavator brought up fragments of a wooden structure during the construction of a new tidal container dock in the port of Antwerp, the Deurganckdok, near the town of Doel (Fig. 1). It was soon clear that the excavation works had hit the archaeological remains of a wooden ship, which came to be called Doel 1. The ship (Fig. 2) was lying upside down in a silted-up gulley, which had been connected to the river Scheldt during the Middle Ages.

Specific characteristics of the ship-find, which measured $c .21 \mathrm{~m}$ long and $7 \mathrm{~m}$ at its widest point, are the straight keel plank with a sharp and angular transition to the straight and steep stem and sternpost, and the flat bottom, built with flush-laid planks. Hull planks from higher strakes are partly overlapping (lapstrake) and are made watertight with moss caulking, tarred and sealed with wooden laths secured by iron sintels. Through-beams support the entire construction. They protrude through the hull, and are protected by fairings ${ }^{1}$ (Fig. 2b). All these characteristics immediately pointed towards the classification of the ship-find as a cog (Van Hove, 2005: 52; Vlierman, 2006); a type of seagoing vessel commonly used from the middle of the 12 th to the beginning of the 15 th century for bulk trade along the shores of the Baltic and North Sea (see Crumlin-Pederson, 2000; Van de Moortel, 2011: 82-9). The local Archaeological Service Waasland (ADW), supported by a specialist from the Netherlands Institute for Ship and Underwater Archaeology (NISA), was entrusted to record, document and salvage the entire wreck within a very short period (Van Hove, 2005: 53). It was decided to dismantle the entire ship, and to store all wooden elements in 29 large $(5-8 \times 2.3 \times 1 \mathrm{~m})$ metal containers, filled with water. For this purpose, planks that measured up to $11 \mathrm{~m}$ long were sawn into manageable pieces that would fit in the containers. The ship timbers remained submerged in water and stored in the containers on a secured location at Antwerp harbour until 2010, when, finally, a post-excavation research and conservation project was started. This project was entrusted to Flanders Heritage Agency and included detailed recording with FARO equipment of all ship timbers, the archaeological interpretation of the find (Vermeersch et al., 2011), botanical analysis of caulking material (Deforce et al., in preparation), gas chromatography-mass spectrometry of tar samples (Burger, 2012) and dendrochronology. Such a multidisciplinary approach was paramount to retrieving detailed information on the ship's age, origin, history and construction, as traces of the cargo or clear archaeological context were lacking in this particular ship-find. Simultaneously, the structural condition and the inorganic content of the wood were assessed in order to set up a plan for conservation and display (Jensen et al., 2011). 


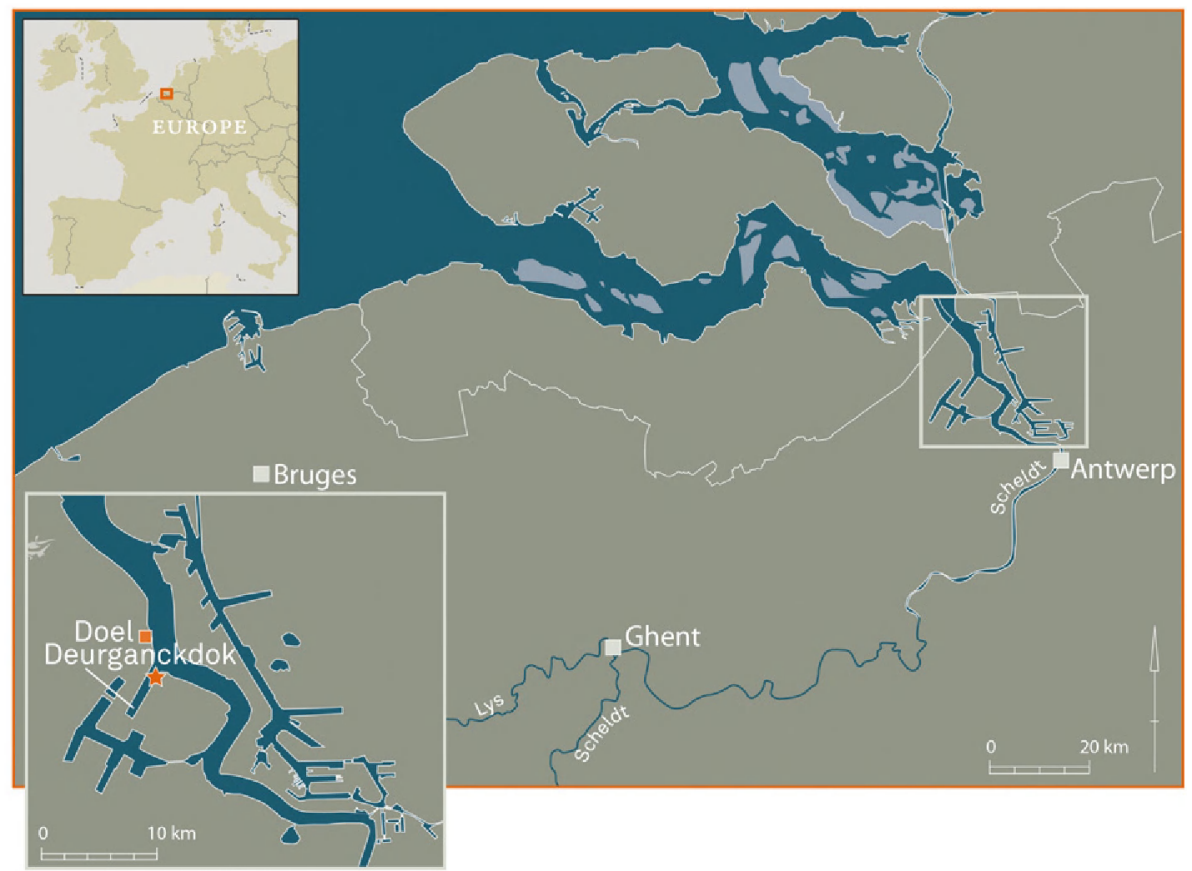

Figure 1. Location of the Doel 1 shipwreck at the Deurganckdok, near Antwerp, Belgium (WGS84: 51 $17^{\prime} 53.65$ N; $^{\circ} 16^{\prime}$ $\left.10.96^{\circ} \mathrm{E}\right)$. (Drawing: Glenn Laeveren)
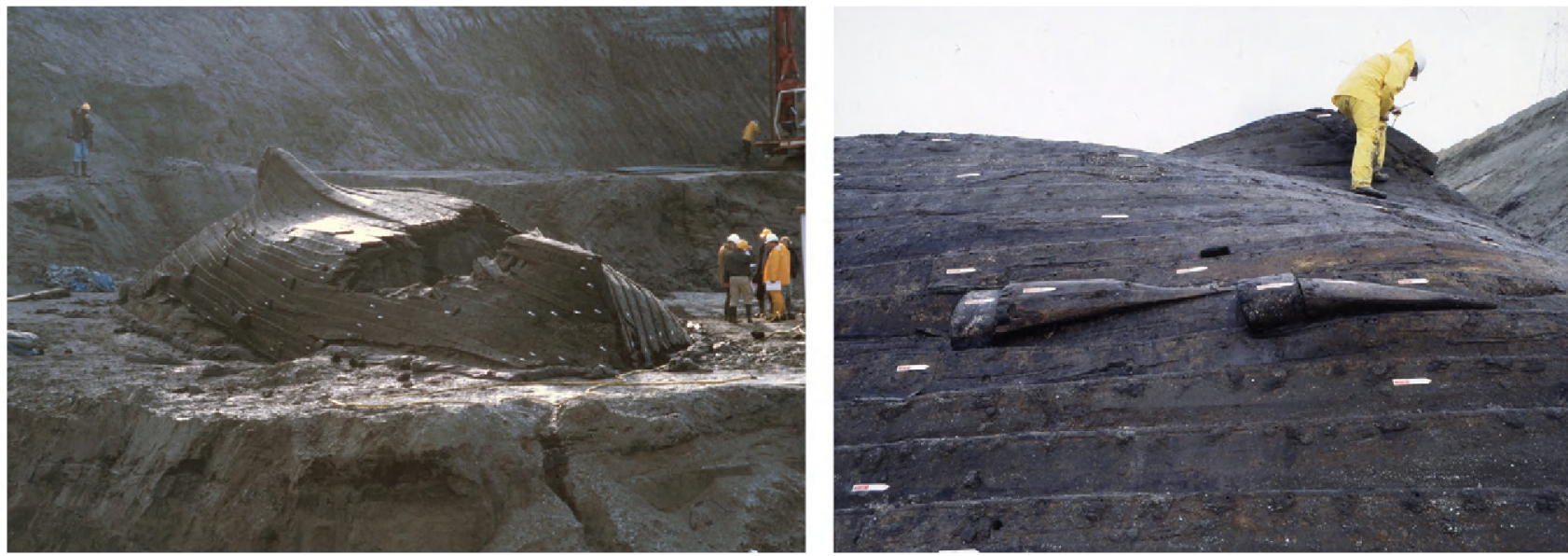

Figure 2. a) Doel 1, in situ (2000), b) detail of the hull and fairings. (@ Archaeological Service Waasland)

To determine the exact dating of the cog, a first dendrochronological examination was undertaken during the salvage campaign in 2000. Four framing timbers and 14 planks were sampled and analysed at the RING Foundation in the Netherlands. Two framing elements still contained bark edge, providing a felling date for those timbers between summer 1325 and spring AD 1326 (Hanraets, 2000). Within the framework of the current research project, tree-ring analysis was again implemented to confirm the established felling date, and to verify whether other ship timbers provided evidence for additional felling dates. The latter could indicate long-distance timber trade, long-term storage at local timber markets (stockpiling) and/or repairs. Especially when there is evidence of repairs on hull planks, their felling date could provide information on the life-span of such a vessel. Furthermore, in order to trace the location of the original construction site, a detailed provenance analysis was performed on a large dataset of tree-ring-width series from the ship timbers. Again, special attention was paid to repairs. Finally, since all timbers were meticulously recorded using a FARO-arm and examined (tree-ring analysis and recording of tool marks), an assessment of the craftsmanship of the shipwright(s) and their level of expertise in timber selection and conversion, as well as in shipbuilding techniques in general could be undertaken. 


\section{Materials and methods}

\section{Wood species identification}

Some specific wooden elements of Doel 1, for example the fairings and a selection of moss laths, were examined in order to identify the botanical species, based on wood anatomical features. Wood chisels were used to take small blocks of $c .1-2 \mathrm{~cm}^{3}$. Thin sections were studied under a transmitted-light microscope and taxonomic identification was performed using identification keys (Schweingruber, 1990), illustrated atlases of microscopic thin sections (Schweingruber, 1990; Wagenführ, 2007), and online databases of wood anatomical descriptions accompanied by images showing anatomical details ['Inside Wood', http://insidewood.lib .ncsu.edu/search (Wheeler, 2011) and 'Wood anatomy of Central European species', www.woodanatomy.ch (Schoch et al., 2004)].

\section{Recording the tree-ring patterns}

In order to record the tree-rings on the ship timbers, conventionally a transverse section of the wood needs to be accessible. Since many of the hull planks had already been sectioned into smaller parts to fit into the storage containers, a relatively smooth transverse surface was accessible on a large number of the ship timbers. On these cross-sections, a narrow strip, c. $10 \mathrm{~mm}$ wide, was pared with scalpels and razor blades in order to highlight the tree-ring boundaries. On framing timbers that were not sawn before storage, the tree-ring pattern was, in some cases, accessible on the joggles. Other timbers without a clean transverse end-surface, that potentially contained relevant information, were sawn to make the tree-ring pattern accessible. After surface preparation, sequential images of the tree-ring pattern were made with $c .1 / 3$ overlap, using a digital camera (Canon, EOS 550D, 18Mpix) with macro-lens (Canon EF-S60mm f/2.8 macro), mounted on a focusing rack (Novoflex, castel-XL) oriented parallel to the cross-section (Fig. 3). This yielded images that could be stitched automatically, using the Panorama module in Photoshop ${ }^{\text {TM }}$ (Photoshop CS5 $>>$ File $\gg$ Automate $\gg$ Panorama $\gg$ Collage), into one high-resolution image of the whole tree-ring pattern. After calibration, tree-ring widths were measured on these high-resolution images using Stream Essentials ${ }^{\mathrm{TM}}$, a software package by Olympus for image acquisition, archiving and documentation.

\section{Tree-ring data analysis}

Using TriCYCLE (Brewer et al., 2011) all ring-width measurements were converted into the appropriate data formats for further analysis. Cross-dating and chronology building was performed using TSAPWin (Rinn, 2003), and based on $t_{\mathrm{BP}}$-values (Baillie and Pilcher, 1973), the percentage of parallel variation $(\% \mathrm{PV})$ and visual assessment.

Some of the series originated from the same ship element, but the growth pattern was registered on

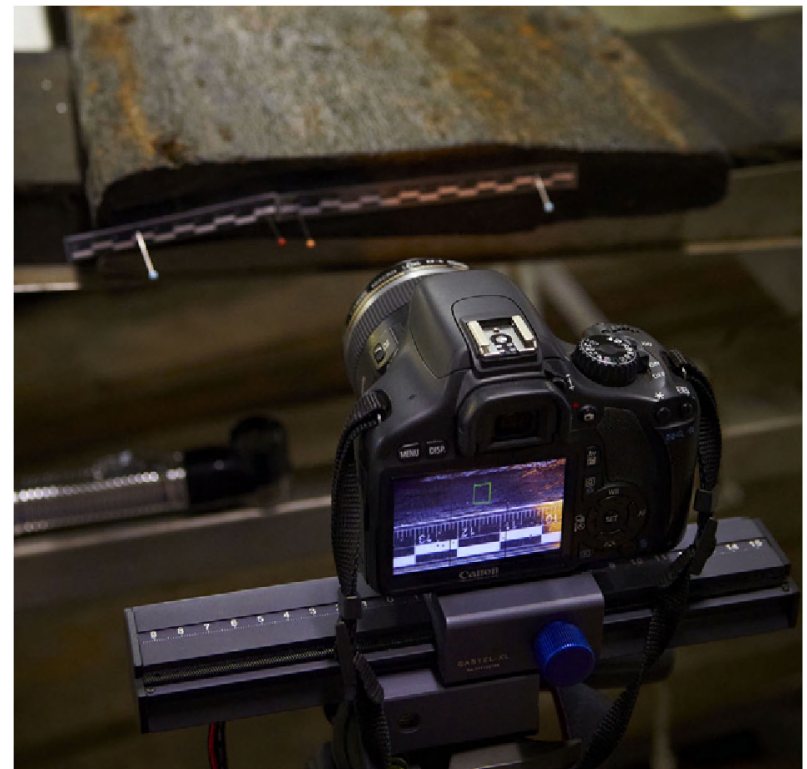

Figure 3. Macro-photography with a focusing rack, to obtain overlapping high-resolution images of the wood anatomy along a pared strip. (Photo: C K. Vandevorst, Flanders Heritage Agency)

different locations along the timber (for example, hull planks that were sawn into separate pieces during salvage). Therefore, for further analysis, all series belonging to one individual timber were averaged into one single tree-ring series. For provenance analysis, all synchronized tree-ring series that were treated as a group, were first averaged into a chronology based on raw values. The resulting chronology was then trimmed at a sample depth of at least ten series. Finally, in order to attain a measure of the extent of internal correlation of the tree-ring series from the ship's timbers, the software package detrendeR (Campelo et al., 2012) was used to calculate the mean correlation between all series $\left(r_{\mathrm{bt}}\right)$ and the expressed population signal (EPS) (Briffa and Jones, 1990) for a window length of 50 years, lagged by 1 year for each run.

\section{Results}

\section{Wood species identification}

All ship timbers of Doel 1 (hull planks, framing timbers, ceiling planks, etc.) are made of European oak (Quercus robur or $Q$. petraea), a highly appreciated species for the production of all kinds of construction timber, due to its excellent mechanical properties and natural durability of the heartwood. It is a highly valued species in dendrochronological research on wooden cultural heritage in Europe, also (Haneca et al., 2009). From the smaller elements of the ship, a sample of 28 moss laths were examined and all of them were made of split strips of oak wood, as were most 
of the treenails as well. One exception is a treenail made of beech wood (Fagus sylvatica). However, it cannot be excluded that more treenails were made out of this or another species, as they were not examined systematically.

In contrast to all major ship timbers of Doel 1, the fairings (Fig. 4) are not made of oak, but shaped out of alder wood, Almus glutinosa or A. incana. Further differentiation between these two botanical species is not possible based on their wood-anatomical features.

\section{Tree-ring series, timbers and trees}

In total, 150 tree-ring series were recorded, of which 132 were measured during the current project and 18 by the RING Foundation shortly after salvage (Hanraets, 2000). After averaging the series obtained in different parts of the same timber elements, the dataset was reduced to 110 individual tree-ring patterns at 'timber level'. This dataset includes hull planks (42), framing timbers (46), ceiling planks (4), throughbeams (4) and repair planks (8). Furthermore, the treering pattern of a clamp, the keel plank, the inner sternpost and the outer stem was recorded. The keelson was heavily damaged by the mechanical excavator, and was salvaged in 2000 in three pieces. On two of those, the tree-ring patterns were recorded. As can be seen from Figure 4, the dendrochronological dataset represents a good sample for the entire ship, both in coverage and spread.

In a next step, it was attempted to synchronize all 110 series. In some cases this yielded conspicuously high values for both $t$-statistics $\left(t_{\mathrm{BP}} \sim 10\right)$ and the percentage of parallel variation ( $\% \mathrm{PV} \sim 85 \%)$, indicating that these timbers (pairs of timber elements in all cases, Table 1) were fashioned from the same log or parent tree. After visual verification, these sequences were averaged into a mean series, further reducing the dataset to 98 growth patterns at 'tree level'. Also, a labelling error was revealed, since a sample labelled S1-3SB in the RING report (Hanraets, 2000) turned out to have the same growth-ring pattern as framing timber S13-SB, suggesting these series belonged to the same piece of timber, and that a sample was sawn off for the dendrochronological analysis in 2000. Furthermore, for one floor timber (S6-SB), the associated futtock (S6-1SB) was shaped from the same log. A set of two smaller floor timbers, S35-BB and S35-SB, also originate from the same tree.

These series at 'tree level' were then compared to absolutely dated reference chronologies, (partly) covering north-western Europe. For 58 series reliable dating results were found, with $t_{\mathrm{BP}}$-values above 5 , replicating on different regional and site chronologies. In terms of dating ratio this means that at timber level $63.6 \%$ ( 70 out of 110 ) of the elements could be dated, and at 'tree level' this ratio becomes $59.2 \%$ (58 out of 98). However, it should be clear that, prior to sampling, timbers already went through an expert selection based on a rough estimate of their number of annual rings. It is likely that such prior selection artificially increased the dating ratio compared to a random choice of ship timbers.

\section{A single felling date?}

All 70 dated ship timbers, including five repair planks, have end-dates that range from AD 1191 up to 1325 (Fig. 5). However, only ten of those contained sapwood rings (SWR). Among them were two futtocks that still retained the bark, allowing the determination of their felling date with very high precision. The outermost ring on these futtocks dates to AD 1325, and consists of earlywood and a considerable amount of latewood (Hanraets, 2000). The latter locates the felling date between the end of the summer of AD 1325 and the first quarter of AD 1326. A felling date later than early spring AD 1326 is not possible, since newly

Table 1. Ship timbers that originate from the same parent tree. Keycodes of average series at 'tree level' end with $T$. Average series on 'timber level' end with $m B B$ (portside) or $m S B$ (starboard). Others are single series. The length of the series is given between brackets. ( $t_{B P}=t$-value according to the Baillie and Pilcher (1973) algorithm; \%PV=percentage of parallel variation, the level of significance $p$ of $\% \mathrm{PV}$ is indicated by *.** or ***, corresponding to $p<0.05, p<0.01$ and $p<0.001$ respectively; $O V L=$ overlap; l sample analysed by RING, but erroneously labelled

DOEL1_GB2mSB (84)

DOEL1_01T (95)

DOEL1_02T (88)

DOEL1_03T (165)

DOEL1 04T (103)

DOEL1_05T (81)

DOEL1 06T (111)

DOEL1_07T (116)

DOEL1_08T (159)

DOEL1_09T (106)

DOEL1 10T (167)

DOEL1_11T (158)

DOEL1_12T (104)
DOEL1 GB2mBB (95)

DOEL1_GF3mSB (72)

DOEL1_GQ1mBB (165)

DOEL1_GJ1mBB (103)

DOEL1_GM2mBB (69)

DOEL1_GO1mBB (91)

DOEL1_GL2mSB (110)

DOEL1_S13-SB (159)

DOEL1_S6-SB (104)

DOEL1 GD3-BB (89)

DOEL1_S35-SB (176)

DOEL1_GC2mBB (51)
DOEL1 GK1mSB (88)

DOEL1_GR1mBB (91)

DOEL1_GK2-BB (72)

DOEL1_GJ1-SB (61)

DOEL1_GP2mBB (67)

DOEL1_GN2mSB (95)

DOEL1_S1-3SB (159)1

DOEL1_S6A-1SB (90)

DOEL1 GD3-SB (122)

DOEL1_S35-BB (158)

DOEL1_GC3mSB (99)
$t_{\mathrm{BP}}$

$\% \mathrm{PV}$

OVL

$\begin{array}{rlr}11.0 & 78^{* * *} & 84 \\ 10.7 & 82^{* * * *} & 72 \\ 11.9 & 77^{* * *} & 91 \\ 10.6 & 80^{* * *} & 72 \\ 10.6 & 94^{* * *} & 49 \\ 11.7 & 82^{* * *} & 47 \\ 15.7 & 82^{* * *} & 89 \\ 14.1 & 79 * * * & 136 \\ 10.6 & 82^{* * *} & 88 \\ 7.6 & 84^{* * *} & 44 \\ 6.2 & 59 * & 150 \\ 7.1 & 77^{* * *} & 46\end{array}$



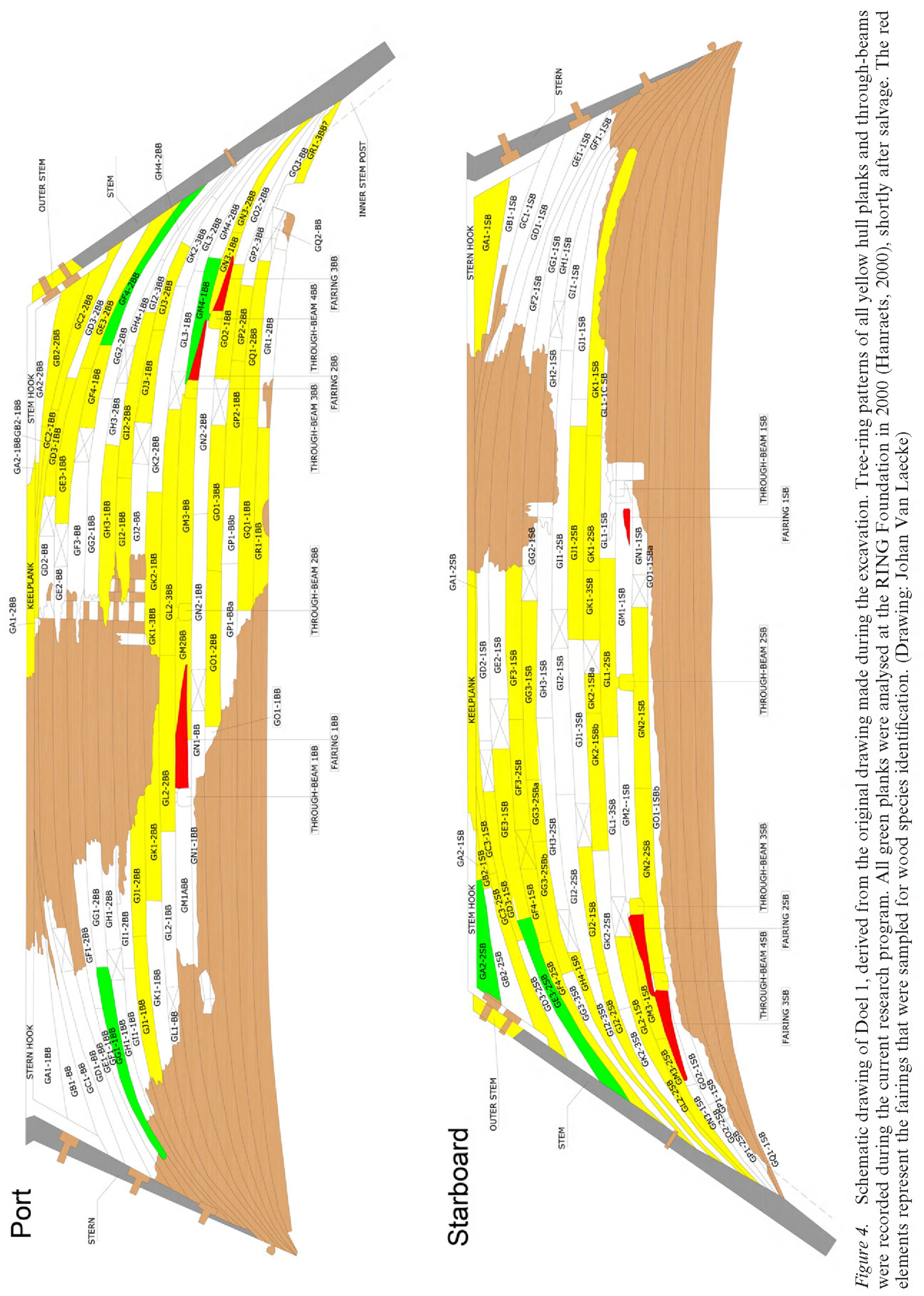


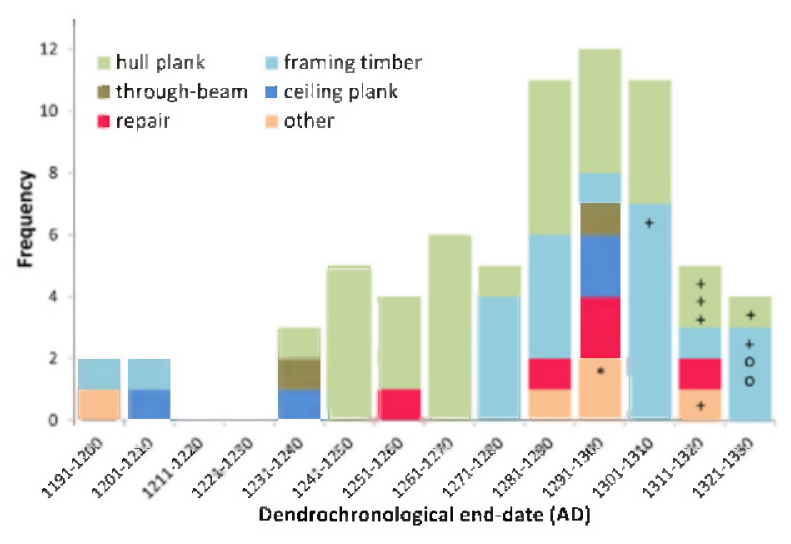

Figure 5. Distribution of the dendrochronological enddates of all 70 dated timbers. A + indicates a series with incomplete sapwood, ${ }^{\circ}$ represents a timber with bark and * the keel plank

formed earlywood vessels would have been observed (Frankenstein et al., 2005; Sass-Klaassen et al., 2011).

Subsequently, all dated samples with incomplete sapwood were used to build up a Bayesian model in order to verify whether these samples pointed towards the same felling date. For estimating the missing number of sapwood rings, the remodelled Hollstein (1980) dataset was used (see Haneca and Debonne, 2012 for more details) and implemented in OxCal (v2.2, Bronk Ramsey, 1995; 2009). However, this model failed when including all eight samples from Doel 1 with incomplete sapwood. The keel plank, which contained 15 SWR, gave a poor agreement with the other items in the model [A: 27.1\%, critical agreement $\%(\mathrm{Ac})=60 \%$. Leaving it out resulted in a model that supports a common felling date between AD 1322 and 1327 for all the timbers with incomplete sapwood (Fig. 6), perfectly in line with the two samples with complete sapwood and bark (felling date AD 1325/26). For the keel plank, however, a felling date between 1307 and 1327 is proposed [95.4\% confidence interval (C.I.)], based on the Hollstein sapwood model taking into account the age of the tree. Although it cannot be ruled out that the tree from which the keel plank was fashioned was cut at the same time as the other timbers, the probability is very low (Fig. 7).

Although it is known that the number of sapwood rings in oak trees from NW-Europe covers a wide range (7-66 according to Hollstein, 1980: 33-5), the chances are very low that this would be the case for the keel plank. There are no indications that this sample could have an exceptionally high number of sapwood rings, since average ring width $(1.81 \mathrm{~mm})$ and standard deviation $(0.789 \mathrm{~mm})$ are within the range of most of the other measured ship timbers.

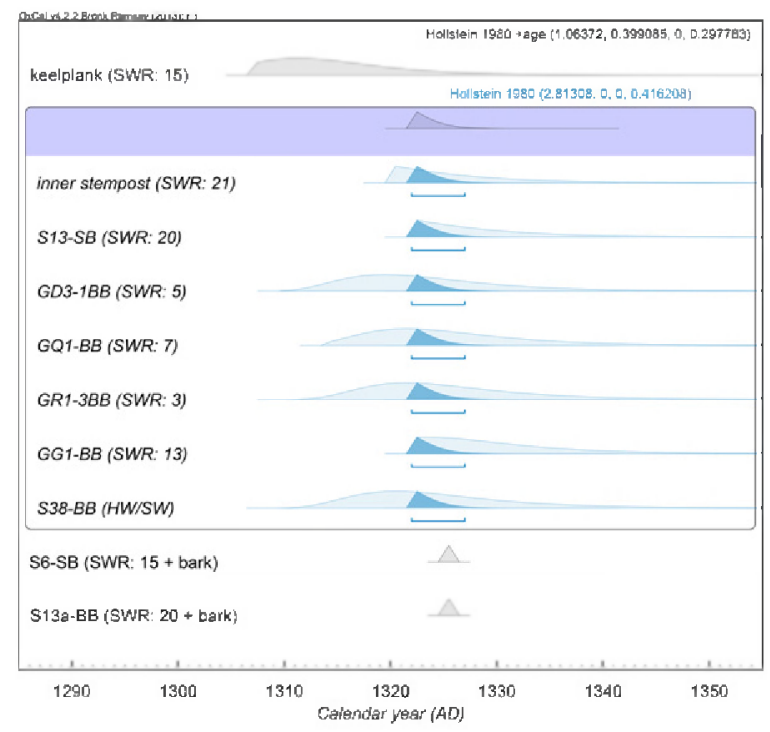

Figure 6. Combined sapwood estimates for all samples with incomplete sapwood, excluding the keel plank which seems to have an earlier felling date. Two samples had complete sapwood and bark attached. Probability density functions were computed using OxCal. (SWR = number of sapwood rings; HW/SW = heartwood/sapwood boundary)

\section{Provenance analysis}

All ship timbers

Surprisingly, exploring the common signal within the dated subset of all recorded tree-ring series, a very low internal correlation became apparent. Values for $r_{\mathrm{bt}}$ and EPS range between $0.068-0.223$ and $0.60-0.89$ respectively, within the interval AD 1200-1300 (computed for 50-year windows), where sample depth fluctuates between 19 and 37 dated samples. Furthermore, a crosscorrelation table (Fig. 7), based on $t_{\mathrm{BP}}$-values and a common overlap of at least 50 years, clearly illustrates that $t_{\mathrm{BP}}$-values rarely exceed 5 . As a consequence, it was very hard, if not impossible, to identify subgroups of timbers that have a clear common signal. However, a few tree-ring series do show a good agreement $\left(t_{\mathrm{BP}}-\right.$ values between 5.4 and 9.2; Fig. 7), but visual comparison made it clear that these series do not originate from the same parent tree. These clusters were used as the starting point to build up a chronology (a similar procedure was presented by Eckstein et al., 2009). The series were averaged into a mean series and compared to the other dated tree-ring patterns. Series displaying a good agreement with the mean series, based on $t_{\mathrm{BP}}$ values over 4.0 and $\% \mathrm{PV}$ above 65 , were added to the chronology. Repeating this hierarchical procedure time and again, resulted in a final chronology including nearly all of the dated series.

Therefore, although the internal correlation between the tree-ring patterns of the ship timbers is very low, it was decided to merge the dated series into a single chronology for further analysis (label: Doel1_all_m2; span: AD 1150-1305), in an attempt to boost their 


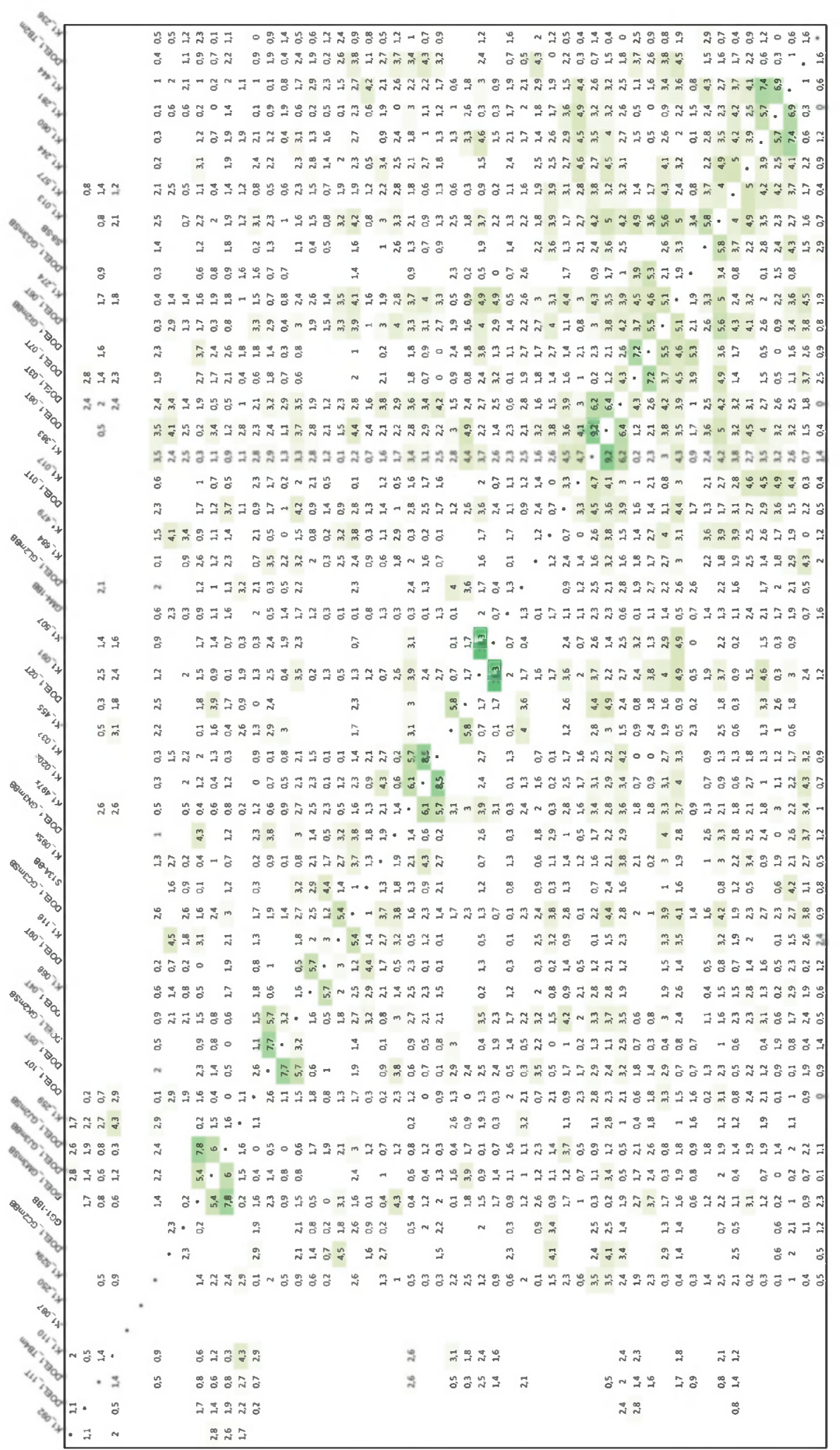

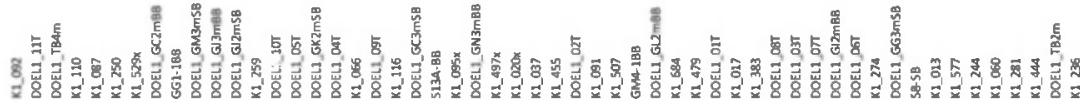

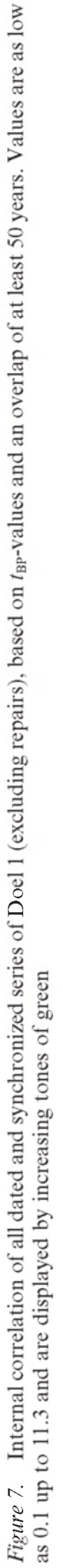

(c) 2013 The Authors. International Journal of Nautical Archaeology (C) 2013 The Nautical Archaeology Society 


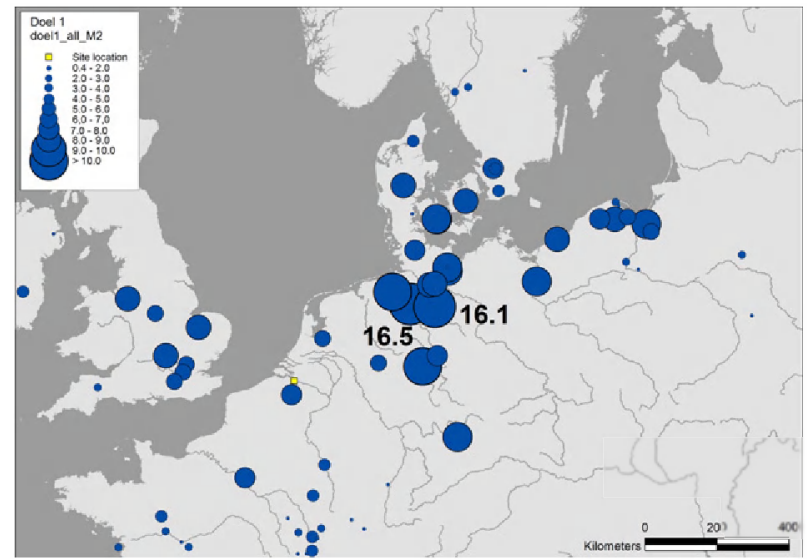

Figure 8. Correlation analysis, based on $t_{\mathrm{BP}}$-values and an overlap of $\geq 50$ years, of the average chronology for Doel 1 , composed of the tree-ring series of all dated ship timbers excluding the repairs. All dots represent a regional master chronology (Daly, 2007) and their size is proportional to the $t_{\mathrm{BP}}$-value achieved

common signal. This average chronology was then compared to a dataset of available regional master chronologies, site chronologies and single series that have been georeferenced to their find location (outline of this methodology in Daly, 2007; 2011a). Clearly, the reference chronology representing the northern part of Belgium (that is Flanders; Haneca, unpublished data), closest to the ship-find, displays a relatively low correlation with the Doel 1 ship timbers chronology $\left(t_{\mathrm{BP}}=4.3\right.$; $\left.\% \mathrm{PV}=62^{* *}\right)$, demonstrating that the find location is not close to the timber source used to construct the ship. The highest correlation values were found with chronologies covering NW Germany (Fig. 8), with very high $t_{\mathrm{BP}}$-values ranging up to 16.5 .

\section{Framing timbers vs. hull planks}

The same routine was performed for the hull planks (label: Doel1_planks_m2; span: AD 1166-1287) and framing timbers (label: Doell_timbers_m2; span: AD 1190-1296) separately. Although there are no dendrochronological arguments to support this division, this procedure was followed to verify whether these two functional groups of timbers could have a different provenance. It is well-known that timber was tied together and rafted downstream along major rivers systems (Eissing and Dittmar, 2011; Haneca and Debonne, 2012: 32; Houbrechts, 2008: 17-25; Van Prooije, 1990). Therefore it might be argued that stems or squared logs are more suited for this kind of bulk transport (Daly, 2011a: 107) compared to the sometimes big and heavy Y-shaped timbers that were used to make floor timbers or futtocks. Where the latter are more difficult to manipulate and handle, they might be harvested closer to the construction site compared to the planking.

Nevertheless, it turned out that, based on the correlation maps (Fig. 9), both groups of timber have a

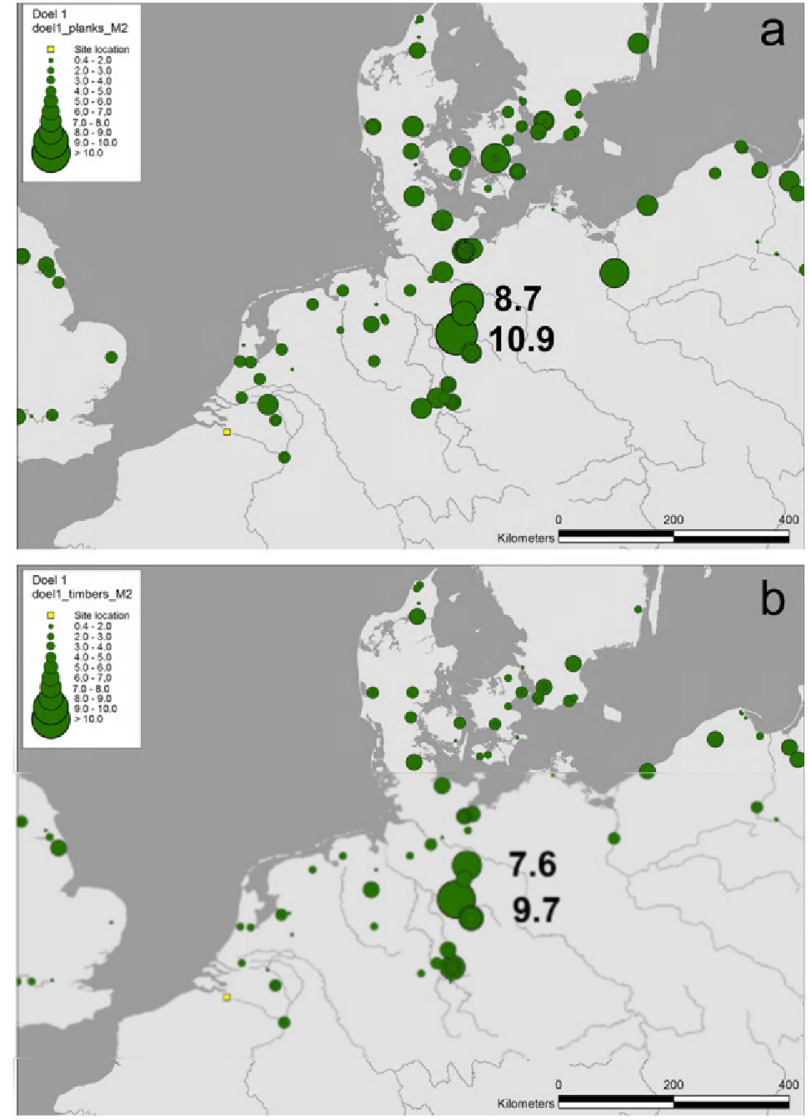

Figure 9. Correlation analysis, based on $t_{\mathrm{BP}}$-values and an overlap of $\geq 50$ years, of the $a$ ) average chronology for the hull planks of Doel 1 (Doel1_planks_m2), and $b$ ) the chronology composed of the tree-ring series of all dated framing timbers of Doel 1 (Doel1_timbers_m2). All dots represent a chronology made from the tree-ring data from one archaeological site (Daly, 2007) and their size is proportional to the $t_{\mathrm{BP}}$-value achieved

similar region of origin, that is NW Germany. More specifically, site chronologies located within the catchment area of the rivers Elbe and Weser display the highest correlation values with planks and framing timbers of Doel 1. Peak values for $t_{\mathrm{BP}}$ up to 10.9 for the planks, and 9.7 for the framing timbers were reached. Furthermore, it is with the same site chronologies that the highest $t_{\mathrm{BP}}$-values with the mean chronology of planks and framing timbers occur.

\section{The through-beams}

Two of the four through-beams analysed could be dated. There is a very short overlap between the two, but they date each independently with site and master chronologies for the NW German region, indicating the same region of origin as the planking and framing elements.

\section{Repairs}

In total, the ring-width pattern of eight repair planks were measured, of which five could be dated. Three of 


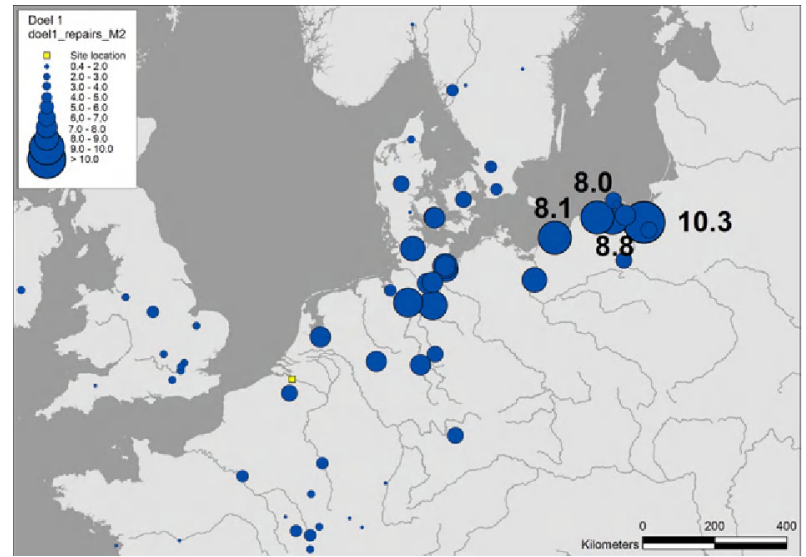

Figure 10. Correlation analysis, based on $t_{\mathrm{BP}}$-values and an overlap of $\geq 50$ years, of the average chronology for three repair planks on Doel 1 (Doel1_repairs_m2). All dots represent a regional, master chronology (Daly, 2007) and their size is proportional to the $t_{\mathrm{BP}}$-value achieved

the dated repair planks display a synchronizing growth pattern and were merged into one average chronology, trimmed to their common overlap (label: Doell_repairs_m2; span: AD 1142-1281). The two remaining dated repairs were treated separately as they did not show any mutual correlation. However, compared to regional oak chronologies, these two series display a relatively good correlation with a set of chronologies covering NW Germany, similar to the bulk of the ship timbers. Repeating this procedure for the Doel1_repairs_m2 chronology, a clear cluster of high $t_{\mathrm{BP}}$-values (with peak values up to 10.3 ) emerges with chronologies composed from wood from northern Poland (Gdansk region) (Fig. 10). It is obvious that the wood of these three repair planks has a different provenance than the bulk of the ship timbers (Figs 8 and 9a-b).

One of the dated repair planks, with a southern Baltic provenance, has an end-date of AD 1320. However, no sapwood was observed and there were no indications that the last ring was located close to the heartwood-sapwood boundary. In order to estimate the earliest possible felling date for this repair plank, sapwood statistics for Poland were consulted (Ważny, $1990 ; 170-73$ ) and a lognormal distribution was fitted to the original data (OxCal model parameters: $a=$ 2.752901, $\sigma=0.293951$ ). This allowed calculation of the average number, in this case 19 , and the $95.4 \%$ C.I. of the expected number of sapwood rings for this region, having a lower and upper limit of 7 and 26 . Adding the lower limit to the end-date of the repair plank, that is $\mathrm{AD} 1320 \mathrm{AD}$, the earliest possible felling date becomes AD 1327 AD.

While capturing the ring-width pattern of the eight repair planks, it had been noticed that all of these timbers were perfectly radially cleaved (the orientation of the medullary rays are parallel to the surface of the board). Furthermore, the pith was not included and these timbers display a uniform tree-ring pattern without a dominating age-trend or frequent disturbance patterns. Plotting series length, their average ring width and associated standard deviation (flags) of all analysed ship timbers (Fig. 11), the repair planks are located in the lower right corner of the graph, with relatively small flags compared to the other timbers. In general, the average ring width on the planks is $2.09 \mathrm{~mm}$ (s.d. $=0.73$ ), and $1.26 \mathrm{~mm}$ (s.d. $=0.52$ ) for the framing timbers. Repair planks on the other hand have a lower average ring width, and also the standard deviation is much smaller: $0.94 \pm 0.24 \mathrm{~mm}$. This illustrates the fact that these repair planks are characterized by a tree-ring pattern with relatively narrow rings and a stable growth rate, especially when compared to the other ship timbers of Doel 1.

\section{Symmetry in carvel-built layout}

When looking at the distribution of the timbers that originate from a same parent tree over the ship (Table 1), a striking pattern emerges when focusing on the lower strakes of the ship. The examined planks from strake B, C and D seem to have a strict symmetrical layout (Fig. 12), with both planks that originate from a same trunk being positioned on opposite sides of the central keel plank. The tree-ring patterns of the planks of strake A to port and starboard are relatively short (GA2-mSB: 49 and GA2-BB: 33), but do show a good visual match. Although the associated correlation values are relatively low $\left(t_{\mathrm{BP}}=5.2 ; \% \mathrm{PV}=66^{*}\right.$; overlap $=33$ ), these two planks are also considered to originate from a same parent tree, and therefore also fit into the observed mirrored layout of the bottom strakes.

Exploration of the distribution of other planks that originate from the same parent tree on the higher strakes, revealed no specific pattern, indicating a random spread along the ship's hull.

\section{Discussion}

99.9\% oak

Doel 1 was constructed out of oak wood. Only a few smaller parts, a treenail and the six examined fairings, were made of other species. The primary function of the fairings is to prevent obstacles or objects from colliding with and damaging the through-beams that protrude through the hull, by guiding them past the beam ends; hence the fairings have a tapered and streamlined shape. Their shape also justifies the use of the term 'fairing' instead of the more conventional term 'fender', which is used for ship elements that are designed to absorb a direct impact. All the preserved fairings of Doel 1 were consistently made of alder, and therefore this was probably not a random choice. We believe that not only the shape of the fairings protects the through-beams and hull, but also the deliberate choice of a softer hardwood is relevant here. Compared to oak, alder has a lower density 


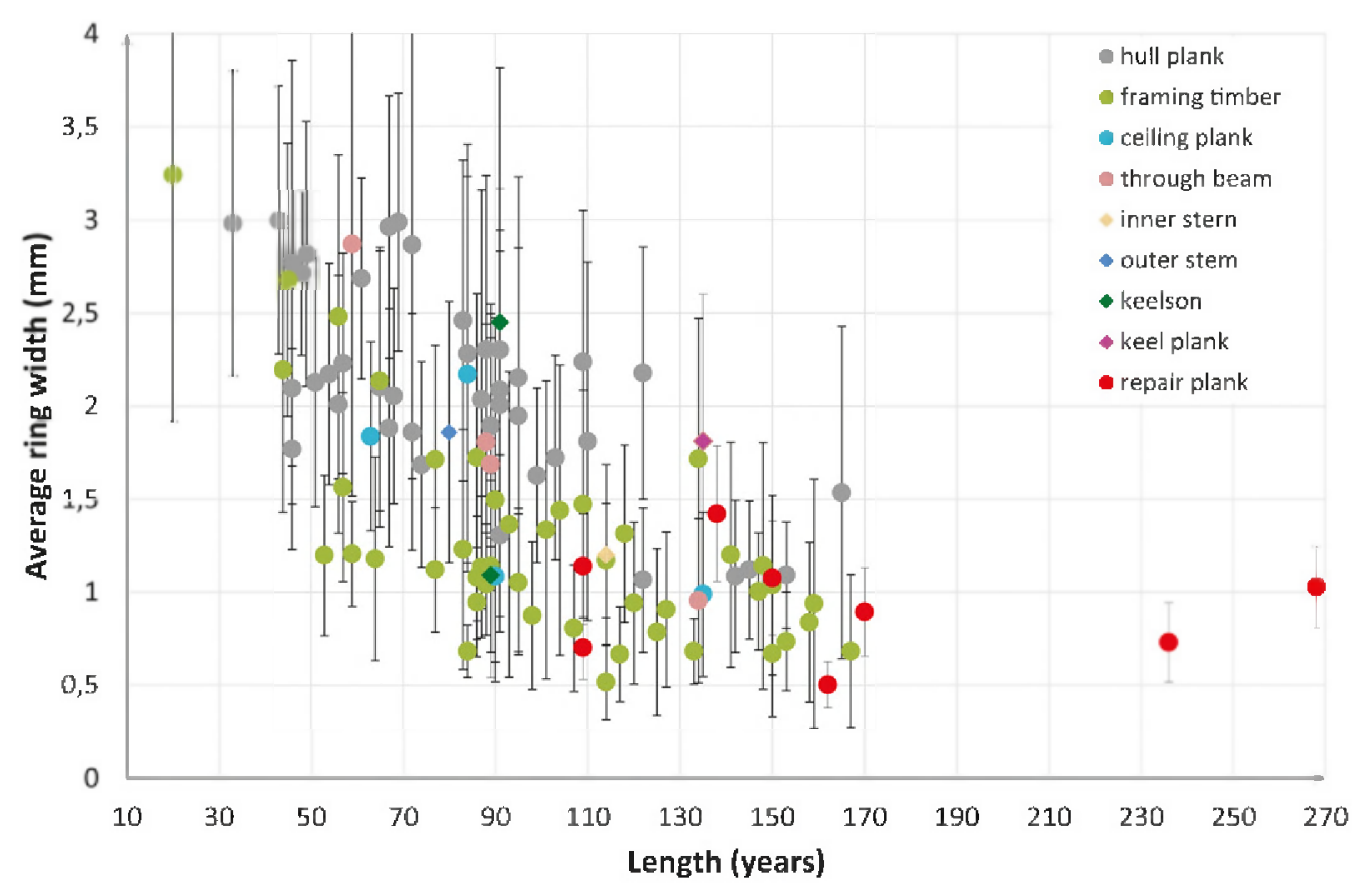

Figure 11. Representation of the length (number of growth-rings), average ring width and standard deviation (upper and lower flag) for each of the 110 analysed ship timbers of Doel 1

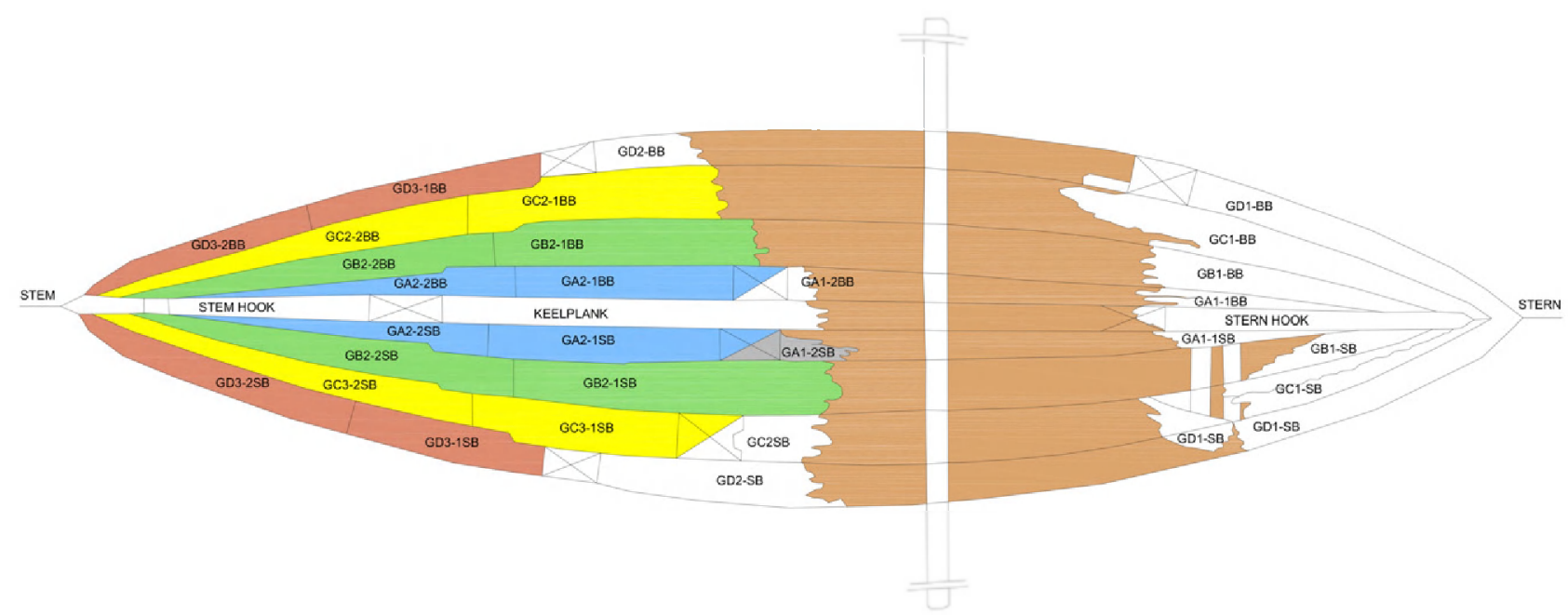

Figure 12. Schematic drawing of the carvel-built bottom-plank strakes A to D (second letter of the label of each fragment). Planks fashioned from the same tree-trunk have an identical colour. (Drawing: Johan Van Laecke)

[alder: (12\%) 490-640 kg/m³ (green) $680-1000 \mathrm{~kg} / \mathrm{m}^{3}$; oak: (12\%) $500-970 \mathrm{~kg} / \mathrm{m}^{3}$, (green) $900-1200 \mathrm{~kg} / \mathrm{m}^{3}$ ], and is considered to be less hard (Janka hardness: alder

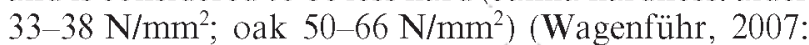
255-60, 276-78). Therefore, on the occasion of an unintended point impact, fairings made of alder are more likely to absorb the (kinetic) energy, causing them to splinter, and having to be replaced. Were the fairings made of oak, they would have the same density and strength properties compared to the hull planks or through-beam, guiding the released forces into the hull and increasing the risk of damage to the planking. Clearly, the former is the preferred scenario, rather than a leak caused by cracked hull planks.

\section{Felling date $=$ construction date?}

For two of the examined ship timbers, tree-ring analysis was able to determine the exact felling date. The question remained whether this $\mathrm{AD} 1325 / 26$ date can be interpreted as the felling date for the bulk of the ship 
timbers. Seven other dated timbers with incomplete sapwood do point towards this date when relating the probability density function of the expected number of sapwood rings to each one of them (Fig. 7). Therefore it seems very likely that all these timbers were collected at the same time for the construction of this ship, which probably took place in or shortly after AD 1326 . Some time needed for transport could be added to the felling date. However, it is most likely that this can be ignored as the freshly cut stems could easily arrive at the shipyard within the year since transport over water (rafting or aboard ships) is not only the most economical way of bulk transport, but also the fastest. Time for seasoning of the wood does not seem to be applicable, as working dry oak is definitely a more laborious task compared to shaping unseasoned timber into planks or framing timbers (Darrah, 1982: 220-22). Furthermore, for Doel 1 the use of 'green' (unseasoned) timber can be inferred, as it can for many cog wrecks, from the frequent appearance of (repaired) cracks down the centre of wide planks. These cracks are usually located near the pith (central tissue in a tree-trunk) where (juvenile) wood has a higher density compared to the wood laid down during the mature stage of a tree's life. Therefore the wood around the pith is more susceptible to shrinking and splitting while drying. Presumably the cracks appeared on the hull planks after green timbers were fastened to the frames by treenails, and had time to season.

Only the keel plank, with a possible earlier felling date, could have been subjected to some pre-treatment before it was used as the backbone of this ship. An explanation for the potential earlier felling date of this tree could be that the wood was stored in water for several months or years, a process referred to as 'ponding'. The main advantage of this technique is that wood can be stored for a long period without any loss of quality related to fungal deterioration or degradation by wood-boring insects. This ancient technique is also supposed to ameliorate the wood's workability and dimensional stability while drying (BoerhaveBeeckman, 1949: 420-24; Crumlin-Pederson, 1986: 142). Furthermore, it is possible that during water storage the natural durability of the wood is improved since starch and other carbohydrates are leached, making it less prone to wood-degrading fungi. Although the latter is certainly true for coniferous wood (Klaassen, 2010), it can be questioned if this holds for oak timber, since the heartwood of oak already has a high natural durability. During (water) storage, gradual release of internal mechanical stress, built up in the stem of a growing tree (growth strain), will occur. This results in wood that tends to warp less while drying and avoids the formation of large cracks. Relaxation of internal stress in timber is a natural process, and a much appreciated (side-) effect of ponding, as it results in dimensionally more stable timber (Boerhave-Beeckman, 1949: 420-24; Crumlin-Pedersen, 1986: 142). Selecting ponded oak timber, free of internal stress and unlikely to develop cracks or warp, for the keel plank, as the backbone of the ship, can therefore be considered as an act of craftsmanship.

For one of the repair planks, its earliest possible felling date is AD 1327. So the year in which this particular oak tree was cut down is certainly situated after AD 1327. Unfortunately, we do not know how much heartwood might have been trimmed off in the shaping of the plank. If we assume that only sapwood was trimmed off and no heartwood rings, the felling date is situated between AD 1327 and 1346 (95.4\% C.I.), with AD 1339 having the highest probability (average number of SWR is 19). This demonstrates that this repair was performed after the completion of Doel 1. To gain more information about the potential life-span of this ship, however, we cannot make a more precise statement based on the dendrochronological date of this repair plank. Nevertheless, it is most likely that this repair was performed a number of years after the construction of the ship. Furthermore, from the archaeological recording of the ship remains and the dendrochronological dataset, it is clear that this ship already had suffered much damage and many major repairs had been performed before it was abandoned.

\section{Provenance}

We now have good indications that Doel 1 was constructed with timbers originating from oak forests located in the vicinity of the rivers Elbe or Weser and their tributaries. As shown on the correlation map (Fig. 8), the highest correlation values were reached with site chronologies from Medingen and Truhen, both data from the University of Göttingen. As such, this provenance determination for Doel 1 is similar to that of the Bremen $\operatorname{cog}$ (Daly, 2009: 115-16). The lack of evident division between the planks and framing timbers, from a dendrochronological perspective, indicates that both types of timber were harvested in the same region. The dendrochronological data from the Bremen cog suggests that the examined through-beam could have a more southern provenance compared to some other ship timbers (Bauch et al., 1967: 290); however, this was not observed for Doel 1 where the tree-ring patterns of the beams have a similar provenance signal as the planks and framing timbers. Defining how broad and how far from the shipyard this region could be is a more difficult matter. At first sight, the low overall correlation between the tree-ring series (Fig. 7) suggests a widely dispersed catchment area for the timber source, with the tree-ring series representing trees that originate from different and distant forest sites. In general, one expects to find higher correlation values for oak trees growing in close proximity. This is especially true when tree growth is subjected to some limiting factor (Fritts, 1976; Schweingruber, 1996:439 548). In such cases the climatological signal embedded in tree-ring series is stronger and, as a consequence, this results in high correlation values for the tree-ring 
patterns of neighbouring trees. However, this would mean that nearly all timbers from Doel 1 originate from different forest sites, which is very unlikely. On the other hand, favourable conditions for oak trees, as is the maritime-influenced climate in coastal NW Germany, not only stimulate vigorous growth (wide tree-rings) but will result in ring-width patterns that do not necessarily display a high agreement with the ring-width pattern of neighbouring trees. Therefore the relatively low correlation between the tree-rings series of the Doel 1 timbers does not necessarily reflect a wide region of provenance.

The distance between the timber source and the shipyard should be discussed taking into account bulk transport of wood along river systems. This has been reported since the Roman times (Domínguez-Delmás et al., in press) and there is a bundant archaeological and documentary evidence for the transport of this bulky wood as rafts since the Middle Ages (Van Prooije, 1990; Houbrechts, 2008: 17-25; Eissing and Dittmar, 2011; Haneca and Debonne, 2012: 32). Furthermore, the transport of timber aboard ships cannot be discarded either. At (local) wood markets, huge amounts of timber were gathered and different assortments were compiled, blending timbers from diverse forest sites and woodlands. Buying timbers from such a wood market that covers a wide region (or entire river catchment) could result in a dendrochronologically diverse assortment of tree-ring series, each representing single forest sites with local (micro-) climates. However, documentary evidence from 16 th to the 18 th century suggests that the selection of timber for shipbuilding was done in the forest, especially for the framing elements (Albion, 1926; De Aranda y Anton, 1990; Domínguez-Delmás et al., 2013: 132). Timber was then brought directly to the shipyard. Therefore it seems unlikely that the timber used to build Doel 1 was purchased at a wood market. Besides, the consistency in felling dates of some structural timbers also supports the hypothesis that these timbers were selected and harvested all at once.

At least three of the examined repair planks clearly have a different provenance compared to the bulk of the original ship timbers (Fig. 10). These repair planks originate from oak trees that probably grew near the mouth of the river Vistula or along the coastal area of northern Poland (Gdansk region). Although the repairs could have been carried out at Gdansk harbour, another location cannot be ruled out, as it is known that timbers with a southern Baltic provenance have been exported and traded all over Europe from the early 14 th century up to $c$. AD 1660 (Wazny and Eckstein, 1987: 511-13; Bonde et al., 1997: 202-3; Ważny, 2005). Furthermore, as these repair planks were radially split timbers, they have all the characteristics of so-called 'wainscots', a high-quality oak timber-product that could be obtained from trees with a fine grain and without major defects, which were one of the most appreciated assortments in the 'Baltic timber trade' (Ważny and Eckstein, 1987: 511-12; Haneca et al., 2005a: 267; 2005b: 290). Most likely, wainscots were widely available in the ports along the North Sea coast, visited by merchants and their ships. Besides, they could have been part of the cargo of Doel 1 as well, readily available for any kind of repair if needed. Indeed, recent discoveries of shipwrecks with cargoes of exactly such planking, at Skjernøysund, Norway (Auer and Maarleveld, 2013), dating to winter AD 13934 and of southern Baltic origin (Daly, 2011b), underline that very possibility. So the location where these repairs were carried out cannot be determined based on the timber provenance as demonstrated by dendrochronology.

\section{Expertise in shipbuilding}

Studying shipbuilding technology is our closest link to the shipwright. It provides insight into the available woodworking technology and the knowledge of the raw material used in the process of constructing a seagoing cargo-vessel. Clearly, the shipwright's expertise is closely related to the range of timber at his disposal. Selection and conversion of timber for specific elements in the construction are fundamental for the final quality and strength of the vessel. Looking at the orientation of the tree-ring pattern on a cross-section of the grain of the wood (the main direction of orientation of tissues and cells), one can deduce the orientation of the timber in the original trunk or branch, and reconstruct the conversion of the tree-trunk. For instance, the Y-shaped framing timbers of Doel 1 are made of forked trees of which one of the branches was cut off, or trees with a heavy side-branch. The remaining, naturally curved piece of timber was then hewn to its desired shape and size. Planking, on the other hand, was sawn. The orientation of the growth pattern on the cross-sections of a sample of 42 timbers (photographed for tree-ring analysis) was categorized according to Figure 13a. It was noted that the bulk of these timbers were flat-sawn, and did not include the pith (Fig. 13b). Only $12 \%$ of this subset of timbers was described as a central plank of a trunk, including the pith (type C), or sawn as a radial plank without pith or sapwood.

How many planks were sawn from one parent log? As most of the planks are of type A, one could assume that at least two planks were sawn from one trunk, one on each side of the pith. Theoretically, more adjacent planks could originate from the same log, but this was not observed in the dendrochronological dataset of Doel 1 (see Table 1). This suggests that the diameter of the original logs was too small to yield more than one pair of planks with an appropriate width for the construction of the bottom and hull. Furthermore, a striking pattern was observed for the bottom of the ship, from strake $A$ to $D$, where the two planks from the same tree-trunk had a mirrored arrangement on both sides of the keel plank (Fig. 12). This detail in construction is sometimes referred to as the 'twin-sister layout'. The symmetrical layout, in terms of wood use, was abandoned on the higher strakes. Nevertheless, such a dedicated plan for the bottom of the Doel 1 ship echoes 


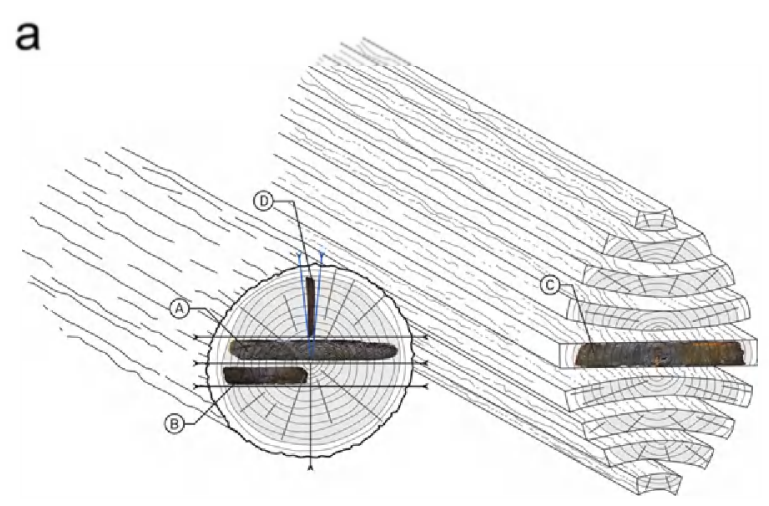

b

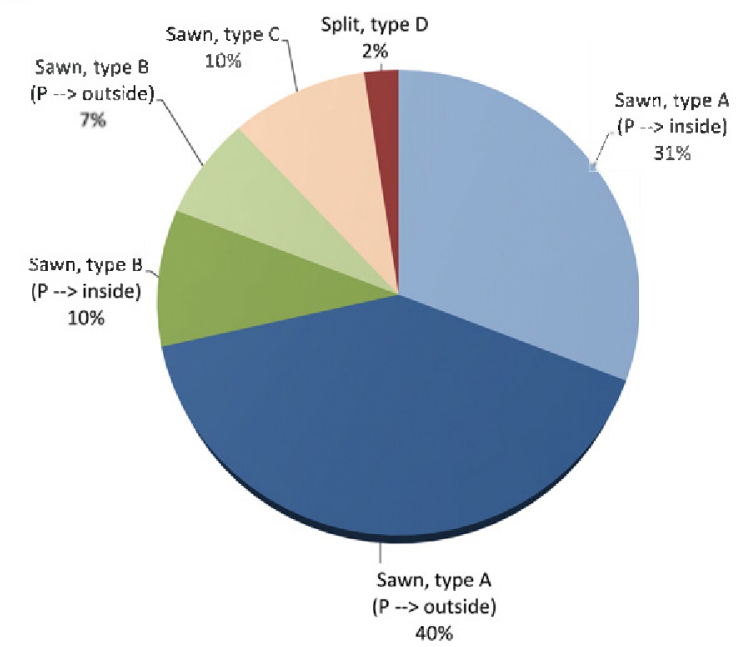

Figure 13. a) Schematic drawing of samples extracted from a split (left) and sawn (right) tree-trunk. Four types of planks are defined. (Drawing: Glenn Laeveren); $b$ ) Division of 42 hull planks according to the schema presented in 13a

the observed layout on several other archaeological ship-finds, where planks converted from the same parent tree are clustered along the hull, for example the Magor Pill boat (Nayling, 1998) or the Bredfjed ship (Bill, 1997a; 1997b). However, this type of layout was mostly deduced from the similar patterns observed in the grain and location of knots on two planks. From a Roman boatbuilding tradition, some examples are also known, for example from the lake of Neuchâtel in Switzerland (Arnold, 1992a; 1992b), the Woerden 7 from the Netherlands (Vorst, 2005) or the Barland's Farm boat (Nayling and McGrail, 2004), as well as medieval examples, such as the OZ36 and Almere wijk 13 cogs from the Netherlands (Bill, 1997b; Vorst, pers. comm.). The strict symmetrical layout of the bottom planks also might suggest that timber arrived at the shipyard as logs, and that the planks were sawn on the spot. The two, fresh-sawn central planks of the trunk were shaped and assembled in flush-lying strakes, on starboard and portside of the central keel plank. Furthermore, the timber chosen to construct the central keel plank was the results of a deliberate selection. The construction of the bottom and the keel of the Doel 1 clearly illustrate the expertise and dedication of the shipwright(s) concerned.

The bottom of the ship was planned systematically in terms of wood use and symmetry, but was this also the case from a wood-technological point-of-view? As can be seen from Figure 13, most timbers did not have the pith included. This could be intentional since planks with the pith included tend to have a higher risk of developing cracks. Furthermore, this orientation of the planks also entails a tendency to warp (Fig. 13a). Despite the neatly worked-out symmetry of the bottom strakes, no attention was paid to the (systematic) orientation of the pith towards the inside or the outside of the ship (Fig. 13b). So it seems this wood-technological feature was not taken into account or considered to be of any importance.

In contrast to the hull planks, all eight repair planks examined were consistently made of radially split oak timbers, which suggests an explicit choice for this grade of timber. This type of wood conversion follows the grain of the wood and, on the condition that they originate from logs without defects and knots, results in timbers that are less sensitive to warping while drying (Crumlin-Pedersen, 1989: 30-1). Such planks can be considered as the most dimensionally stable timbers, and therefore also assured a higher level of 'safety' to the repair.

From the keelson we now have two pieces of timber of which the growth pattern was recorded. The two pieces are located on either side of the hole that was cut in the hull of Doel 1 at its discovery. Both patterns could be dated, and although belonging to the same piece of timber, they do not overlap (gap of 16 years). Does this mean that the keelson was made out of two pieces? Not necessarily, as both locations where the growth pattern was recorded lie at least $4.03 \mathrm{~m}$ apart, not including the gap which is estimated to be around $2 \mathrm{~m}$ wide. This could explain why the tree-ring series do not overlap. Although dendrochronology cannot demonstrate that the keelson was fashioned out of a single piece of wood, from a wood-technological point-ofview it might be considered as a likely choice by the shipwright, since strength properties of a keelson made of two connected pieces could be inferior. Considering the structural function of the keelson to support the mast and sail, a scarf not far aft of the mast-step seems improbable.

\section{Knowledge gain and concluding remarks}

From a dendrochronological point-of-view, the examined ship timbers of Doel 1 provides one of the most comprehensive datasets in nautical archaeology at the level of a single ship-find, alongside the Newport ship and the Mary Rose. In total, the tree-ring pattern of 110 ship timbers was recorded and analysed. For dating purposes, timbers with sapwood or bark were targeted in order to anchor the find in time with the 
highest level of precision. Only those timbers allow us to narrow down the felling date to a precise time interval, to the year or even to the season if the bark edge is preserved as well. This is the most common strategy in dendrochronological studies, and should always be implemented when examining archaeological ship-finds. A narrow selection of easily accessible timbers without sapwood or bark edge from one particular find should not be followed, as this could lead to a post quem date that strongly deviates from the true felling date. As can be seen from Figure 6, some timbers had an end-date for their tree-ring pattern in the interval AD 1191-1200, more than 130 years away from the actual construction date of Doel 1 .

Regarding information gained, the repair planks, the keel plank and the planks from the bottom strakes have proved most interesting. Targeting repair planks that are not part of the initial construction process allows us to gain information about the life-span of the ship and, therefore, their sampling should be considered in similar projects on archaeological ship-finds. In this case one repair timber had its earliest possible felling date certainly after the construction date of Doel 1 , but in cases where sapwood is preserved, such repairs could provide more detailed insight into the life-span of a ship. It was also observed that these repairs were performed with high-quality timber. Furthermore, in terms of wood grading, the tree-ring analysis of the keel plank also provided arguments for the selection of high-quality timbers for structurally important elements of the ship. For Doel 1, there were no indications that this was also the case for other structural timbers such as the stem and sternpost, but should be kept in mind for future research projects.

A common criterion in selecting timbers for dendrochronological analysis is the estimated number of rings that can be measured on a cross-section. Timbers with at least 60-80 rings are usually chosen for further analysis. However, some of the bottom planks of Doel 1 had less than 50 rings. They were measured anyway since a neat cross-section was already accessible, due to the sawing of the planks in 2000. Despite the limited length of the tree-ring series, these growth patterns had an added value as they helped to exemplify the consequent, symmetrical layout of the ship's bottom strakes. Where dendrochronology is solely used as a dating technique, short series will not be registered; but if a systematic approach in the layout of a ship is to be explored, timbers with a low number of tree-rings should also be selected and included in the dendrochronological dataset. Therefore, the need for a research-question driven sampling strategy is demonstrated here.

Finally, we want to stress that this dendrochronological project benefitted from the fact that many planks and timbers were already sawn into manageable pieces during salvage in 2000. Therefore, on many timbers a clean and easily accessible cross-section was available for the registration of the tree-ring pattern. The number of 110 timbers analysed might not necessarily be taken as a normal sample size required for a comprehensive dendrochronological study of the ship. The tree-ring pattern of many samples did not substantially add to the dating of the ship, or change the interpretation of constructional details, but it did supply a detailed picture of the timber procurement strategy that was used. A minimum of ten dated samples for each group of timbers (framing elements, planks) should be strived for in order to obtain qualitative dendro-provenancing results (see for example Domínguez-Delmás et al., 2013: 134). For example, this is in contrast to the dendrochronological-dating and -provenance analysis of the well-known Bremen cog, which is based on only three dated tree-ring series from the cross-beams (Liese and Bauch, 1965: 41; Bauch et al., 1967: 290). In order to obtain qualitative datasets, one should be able to take many samples from an archaeological ship-find. Sampling is often a synonym for sawing timbers in order to get access to the growth-rings. Taking cores from ship timbers is also a possibility; however, this often gives poor results with waterlogged wood as the cores often disintegrate (degradation of the wood), fall into pieces (presence of cracks) or, if sapwood is present, it is often extremely difficult to keep it intact and attached to the heartwood. Furthermore, in the case of Doel 1, due to the use of flat-sawn planks, taking cores that contain the maximum number of tree-rings is very hard due to the strong curvature and orientation of the growth-rings (Fig. 13a). Therefore, the registration of the tree-ring patterns on waterlogged archaeological material should preferably be performed on cross-sections in order to obtain a dendrochronological dataset with the highest quality standard and scientific value, despite the necessity of sawing through the individual ships' components. On the other hand, in the case of air-dried and archived ship timbers, novel techniques such as X-ray CT can provide a non-destructive alternative for obtaining access to the growth-ring pattern (Bill et al., 2012).

\section{Note}

1. For sake of consistency the term 'fairings' is used throughout this paper, although some scholars would prefer to use 'fenders' instead.

\section{Acknowledgements}

We would like to thank Jeroen Vermeersch, Tom Lenaerts and all members of the 'De Kogge' team (Flanders Heritage Agency) for their assistance and valuable input. Esther Jansma was so kind as to give us access to the original measurements made by 
RING in 2000. Yardeni Vorst provided us with appreciated feedback and comparable cases of the twin-sister principle in Roman and medieval shipbuilding. We would also like to thank the two anonymous reviewers whose highly appreciated comments and suggestions helped us to improve the quality of this paper. Carrying out dendrochronological research can never be done without the generosity that colleagues and institutions in northern Europe have shown in making their tree-ring data available, and to those colleagues we are most grateful.

\section{References}

Albion, R. G., 1926, Forests and Sea Power: the Timber Problem of the Royal Navy, 1652-1862. Harvard University Press, Cambridge MA.

Arnold, B., 1992a, Batellerie gallo-romaine sur le lac de Neuchatel: Tome 1. Archéologie Neuchâteloise, 12.1. Saint-Blaise.

Arnold, B., 1992b, Batellerie gallo-romaine sur le lac de Neuchatel: Tome 2. Archéologie Neuchâteloise 13.2. Saint-Blaise.

Auer, J. and Maarleveld, T., 2013, Skjernoysund Wreck 3 Fieldwork Report 2011. Esbjerg Maritime Archaeology Reports 5. University of Southern Denmark.

Baillie, M. G. L. and Pilcher, J. R., 1973, A simple crossdating program for tree-ring research. Tree-Ring Bulletin 33, 7-14.

Bauch, J., Liese, W., and Eckstein, D., 1967, Über die Alterbestimmung von Eichenholz in Norddeutschland mit Hilfe der Dendrochronologie. Holz Als Roh-Und Werkstoff 25.8, 285-91.

Bill, J., 1997a, Tracking professionalism in sixteenth century Scandinavian boat building. The INA Quarterly $24,19-24$.

Bill, J., 1997b, Small scale seafaring in Danish waters, AD 1000-1600. Københavns universitet, Copenhagen.

Bill, J., Daly, A., Johnsen, Ø., and Dalen, K. S., 2012, DendroCT - Dendrochronology without damage. Dendrochronologia 30, 223-30.

Boerhave Beekman, W., 1949, Hout in alle tijden: vol. 5. Deventer.

Bonde, N., Tyers, I., and Ważny, T., 1997, Where does the timber come from? Dendrochronological evidence of the timber trade in Northern Europe, in A. Sinclair, E. Slater, and J. Gowlett (eds), Archaeological Sciences 1995, 201-204. Oxbow Monograph 64, Oxford.

Brewer, P. W., Murphy, D., and Jansma, E., 2011, TRiCYCLE: a universal conversion tool for digital tree-ring data. Tree-Ring Research 67, 135-44.

Briffa, K. R. and Jones, P. D., 1990, Basic chronology statistics and assessment, in E. R. Cook, and L. A. Kairiukstis (eds), Methods of Dendrochronology: Applications in the Environmental Sciences, 137-152. Dordrecht.

Bronk Ramsey, C., 1995, Radiocarbon calibration and analysis of stratigraphy: the OxCal program. Radiocarbon 37, 425-30.

Bronk Ramsey, C., 2009, Bayesian analysis of radiocarbon dates. Radiocarbon 51, 337-60.

Burger, P., 2012, Analysis of tarry caulking materials from the Doel cogs, Belgium. Science report No. PR07379-4, The British Museum, London.

Campelo, F., García-González, I., and Nabais, C., 2012, detrendeR-A Graphical User Interface to process and visualize tree-ring data using R. Dendrochronologia 30, 57-60.

Crumlin-Pedersen, O., 1986, Aspects of Wood Technology in Medieval Shipbuilding, in Sailing into the Past. The International Ship Replica Seminar, Roskilde 1984, 138-49. Roskilde.

Crumlin-Pedersen, O., 1989, Wood technology and forest resources in the light of medieval shipfinds, in C. Villain-Gandossi, S. Busuttil, and P. Adam (eds), Medieval Ships and the Birth of Technological Societies, 1: Northern Europe, $25-42$. Foundation for International Studies, Malta.

Crumlin-Pedersen, O., 2000, To be or not to be a cog: the Bremen Cog in perspective. IJNA 29, $230-46$.

Daly, A., 2007, Timber, Trade and Tree-rings. A dendrochronological analysis of structural timber in Northern Europe, c.AD 1000 to c.AD 1650. University of Southern Denmark,.

Daly, A., 2009, The chronology of cogs and their timber origin, in Bockius, R. (ed.), Between the Seas: Transfer and Exchange in Nautical Technology: Proceedings of the 11th International Symposium on Boat and Ship Archaeology, Mainz $2006,237-48$. Mainz.

Daly, A., 2011a, Dendro-geography. Mapping the Northern European historic timber trade, in P. Fraiture (ed.), Tree Rings, Art, Archaeology: Proceedings of an International Conference, 107-23. Brussels.

Daly, A., 2011b, Dendrochronological analysis of oak from a shipwreck. Skjernoysund 3, Mandal. Norway: Chronology. Culture and Archaeology report 2 (September 2011). Dublin.

Darrah, R., 1982, Working unseasoned oak, in McGrail, S. (ed.), Woodworking Techniques before 1500, 219-28. BAR International Series, Oxford.

De Aranda y Antón, G., 1990, Los Bosques Flotantes: historia de un roble del siglo XVIII. Colección Técnica, Ministerio de Agricultura, Pesca y Alimentación, ICONA, Madrid.

Domínguez-Delmás, M., Driessen, M., García-González, I., Visser, R, and Jansma, E., in press. Long-distance oak supply in mid-2nd century AD revealed: the case of a Roman harbour (Voorburg-Arentsburg) in the Netherlands. Journal of Archaeological Science. DOI: 10.1016/j.jas.2013.09.009.

Domínguez-Delmás, M., Nayling, N., Ważny, T., Loureiro, V., Lavier, C., 2013, Dendrochronological dating and provenancing of timbers from the Arade 1 Shipwreck, Portugal. IJNA 42, 118-36.

Eckstein, J., Leuschner, H. H., Bauerochse, A., Sass-Klaassen, U., 2009, Subfossil bog-pine horizons document climate and ecosystem changes during the Mid-Holocene. Dendrochronologia 27, 129-46.

Eissing, T. and Dittmar, C., 2011, Timber transport and dendro-provenancing in Thuringia and Bavaria, in P. Fraiture (ed.), Tree Rings, Art, Archaeology. Proceedings of an International Conference, 137-49. Brussels.

Frankenstein, C., Eckstein, E., and Schmitt, U., 2005, The onset of cambium activity - a matter of agreement? Dendrochronologia 23, 57-62. 
Fritts, H. C., 1976. Tree-rings and Climate. Academic Press, London.

Haneca, K., Cufar, K., and Beeckman, H., 2009, Oaks, tree-rings and wooden cultural heritage: a review of the main characteristics and applications of oak dendrochronology in Europe. Journal of Archaeological Science 36, 1-11.

Haneca, K. and Debonne, V., 2012, Precise tree-ring dating of building activities despite the absence of bark: A case-study on medieval church roofs in Damme, Belgium. Dendrochronologia 30, 23-34.

Haneca, K., De Boodt, R., Herremans, V., De Pauw, H., Van Acker, J., van de Velde, C., and Beeckman, H., 2005b, Late Gothic altarpieces as sources of information on medieval wood use: a dendrochronological and art historical survey. $I A W A$ Journal 26, 273-98.

Haneca, K., Ważny, T., Van Acker, J., and Beeckman, H., 2005a, Provenancing Baltic timber from art historical objects: success and limitations. Journal of Archaeological Science 32, 261-71.

Hanraets, E., 2000, Rapportage daterend onderzoek. Antwerpen, Doel; kogge. Nederlands Centrum voor Dendrochronologie RING, Amersfoort.

Hollstein, E., 1980, Mitteleuropäische Eichenchronologie: Trierer dendrochronologische Forschungen zur Archäologie und Kunstgeschichte. Mainz am Rhein.

Houbrechts, D., 2008, Le logis en pan-de-bois dans les villes du bassin de la Meuse moyenne, Dossier de la commission royale des monuments sites et fouilles, Liège.

Jensen, P., Straetkvern, K., Gregory, D., and Taube, M., 2011, The Doelse Cog. State of preservation and suggestion for conservation, The National Museum of Denmark Conservation Department, report $\mathrm{n}^{\circ} 11031311-01$.

Klaassen, R. K., 2010, Effect of ponding on the wood quality of Scots pine. Proceedings of the COST-Action IE-0610 workshop in Hamburg: http:/www.woodculther.com/wp-content/uploads/2010/10/klassen-ponded-pine-full-paper.pdf (accessed 27/9/ 2013).

Liese, W. and Bauch, J., 1965, Das Alter der Bremer Kogge. Bremisches Jahrbuch 50, 14-9.

Nayling, N., 1998, Oak dendrochronology, in N. Nayling (ed.), The Magor Pill Medieval Wreck, 116-22. CBA Research Report 115 , York.

Nayling, N. and McGrail, S., 2004, Barland's Farm Romano-Celtic Boat. CBA research report 138, York.

Rinn, F., 2003, TSAP-Win User Reference (version 0.53). Heidelberg.

Sass-Klaassen, U., Sabajo, C. R., and den Ouden, J., 2011, Vessel formation in relation to leaf phenology in pedunculate oak and European ash. Dendrochronologia 29, 171-5.

Schoch, W., Heller, I., Schweingruber, F. H., and Kienast, F., 2004, Wood anatomy of central European Species. www woodanatomy.ch (accessed 27/9/13).

Schweingruber, F. H., 1996. Tree rings and environment. Dendroecology. Berne.

Schweingruber, F. H., 1990, Anatomy of European woods. Bern.

Van de Moortel, A., 2011, Medieval Boat and Ship Finds of Germany, the Low Countries, and Northeast France: Archaeological Evidence for Shipbuilding Traditions, Shipbuilding Resources, Trade and Communication. Settlement and Coastal Research in the Southern North Sea Region 34, 67-104.

Van Hove, R., 2005, De Doelse Kogge(n) Maritiem erfgoed van Europees fromaat. Monumenten. Landschappen \& Archeologie $24,50-69$

Van Prooije, L. A., 1990, Entwicklung der Holzverarbeitung und Flösserei in den Niederlanden im 17. und 18. Jahrhundert, in G. U. Grossmann (ed.), Hausbau in Den Niederlanden: Jahrbuch für Hausforschung 39, 39-48. Marburg.

Vermeersch, J., Lenaerts, T., Haneca, K., Deforce, K., and Van Laecke, J., 2011, The medieval cogs from Doel, Antwerp, Belgium. The Newsletter of the Nautical Archaeology Society, Spring 2011, 8 -9.

Vlierman, K., 2006, The cog finds at Doel. State of affairs of accommodation, documentation and research, in G. Gevaerts, J. Mees, and J. Seys (eds), To Sea or Not To Sea. Second International Colloquium on Maritime and Fluvial Archaeology in the Southern North Sea Area, Brugge 2006. Book of Abstracts, 29-32. Oostende.

Vorst, Y., 2005, De constructie en herkomst van de Romeinse platbodem 'Woerden 7', een studie van jaarringpatronen en bewerkingssporen. Amsterdam.

Wagenführ, R., 2007, Holzatlas. Leipzig.

Ważny, T., 1990, Aufbau und Anwendung der Dendrochronologie für Eichenholz in Polen. Hamburg University, Hamburg.

Ważny, T., 2005, The origin, assortments and transport of Baltic timber: historic-dendrochronological evidence, in C. van de Velde, H. Beeckman, J. Van Ackerand, and F. Verhaeghe (eds), Constructing Wooden Images: Proceedings of the Symposium on the Organization of Labour and Working Practices of Late Gothic Carved Altarpieces in the Low Countries, 115-26. Brussels.

Ważny, T. and Eckstein, D., 1987, Der Holzhandel von Danzig/Gdansk Geschichte, Umfang und Reichweite. Holz als Roh-und Werkstoff 45, 509-13.

Wheeler, E. A., 2011, InsideWood-a web resource for hardwood anatomy. IAWA Journal 32, $199-211$. 